\title{
PENGEMBANGAN INDIKATOR KINERJA UTAMA UNTUK MENGUKUR KEBERLANJUTAN PENELITIAN PADA FAKULTAS TEKNIK UNIVERSITAS DIPONEGORO
}

\author{
Ary Arvianto ${ }^{1}$, Meikel Zekben $\mathrm{S}^{2}$, Naniek Utami Handayani ${ }^{3}$, Purnawan Adi $\mathrm{W}^{4}$, \\ Singgih Saptadi ${ }^{5}$
}

Departemen Teknik Industri Universitas Diponegoro

J1. Prof. H. Soedarto, SH, Tembalang Semarang 50239

Email : aryarvi@gmail.com

\begin{abstract}
Indicators are quantitative and qualitative measures that describe the level of an achievement of a predetermined goal or the aims. The Faculty of Engineering of Diponegoro University, being the largest Faculty as well as the largest contributor to research every year, possesses 2015-2020 Strategic Plan as a guideline. Within the Strategic Plan, there is an IKFT, namely indicators to measure the capacity and achievement of the Faculty of Engineering each year. Specific indicators to assess research capacity and research achievements are still minimal and still need to be developed. This study aims to develop key indicators to assess the research capacity of the Faculty of Engineering of Diponegoro University. Research capacity can be assessed from the four main factors of research sustainability, which are: financial factors, organizational management, research support and infrastructure. In this study, there are nine key indicators developed from journals and other literary sources. There are 11 KPI from FT UNDIP Strategic Plan, and 9 KPI that were developed. These indicators are classified according to the sustainability factors of the study, among others: 6 KPI for financial factors, 3 KPI for organizational management factors, 6 KPI for supporting research and 5 KPI for infrastructure. After being developed, an assessment is carried out by first weighting KPI using the AHP method and then scoring with the OMAX method. From the results of these assessments, Achievement Index of each category were obtained, namely: financial being 7,906, organizational management being 5,628, research support being 4,713 and infrastructure being 8,171. Based on the assessment of each category using the OMAX table, 7 KPI were given red light status, 4 KPI were given yellow light status, and 9 KPI were given green light status. The next step is to design recommendations for improvements from several literatures to increase research capacity and then validate it using the Delphi method.
\end{abstract}

Keywords : Key Performance Indicators, Sustainability of Research, AHP, OMAX, Delphi

\begin{abstract}
ABSTRAK
Indikator adalah ukuran kuantitatif dan kualitatif yang menggambarkan tingkat pencapaian suatu sasaran atau tujuan yang telah ditetapkan. Fakultas Teknik Universitas Diponegoro yang merupakan Fakultas terbesar sekaligus sebagai penyumbang hasil riset terbesar setiap tahunnya telah mempunyai Renstra 2015-2020 sebagai pedoman. Didalam Renstra tersebut terdapat IKFT, yaitu indikator-indikator untuk mengukur kapasitas FT serta pencapaian FT setiap tahunnya. Indikator khusus untuk menilai kapasitas riset dan pencapaian riset masih minim dan masih perlu dikembangkan. Penelitian ini bertujuan mengembangkan indikator kunci untuk menilai kapasitas riset Fakultas Teknik Universitas Diponegoro. Kapasitas riset dapat ditinjau dari empat faktor utama keberlanjutan penelitian yaitu antara lain : faktor keuangan, manajemen organisasi, pendukung riset dan infrastruktur. Dalam penelitian ini terdapat sembilan indikator kunci yang dikembangkan dari jurnal dan sumber literatur lainnya. Terdapat 11 KPI sumber Renstra FT UNDIP, 9 KPI yang dikembangkan. Indikator tersebut digolongkan sesuai faktor keberlanjutan penelitian antara lain : 6 KPI faktor financial, 3 KPI faktor manajemen organisasi, 6 KPI pendukung riset dan 5 KPI infrastructure. Setelah dikembangkan dilakukan penilaian dengan terlebih dahulu melakukan pembobotan KPI menggunakan metode AHP dan kemudian dilakukan scoring dengan metode OMAX. Hasil dari penilaian tersebut didapatkan Indeks Pencapaian setiap kategori antara lain yaitu : financial 7,906, manajemen organisasi 5,628, pendukung riset 4,713 dan infrastruktur 8,171. Berdasarkan penilaian tabel OMAX setiap kategori didapatkan 7 KPI yang posisi lampu merah, 4 KPI yang posisi lampu kuning dan 9 KPI posisi lampu hijau. Tahap selanjutnya dirancang rekomendasi perbaikan dari beberapa literatur untuk meningkatkan kapasitas riset dan kemudian divalidasi dengan menggunakan metode delphi.
\end{abstract}

Kata Kunci : Key Peformance Indicators, Sustainability of Research, AHP, OMAX dan Delphi 


\section{PENDAHULUAN}

\section{Latar Belakang}

Perguruan tinggi adalah salah satu subsistem pendidikan nasional yang ada di Indonesia. Menurut Undang-Undang Nomor 20 Tahun 2003 tentang sistem pendidikan nasional menyebutkan bahwa perguruan tinggi berkewajiban menyelenggarakan pendidikan, penelitian, dan pengabdian kepada masyarakat (Pasal 20 Ayat 2). Perguruan tinggi tanpa adanya penelitian akan dianggap sebagai perguruan tinggi yang tidak produktif, perguruan tinggi yang tertinggal. setiap perguruan tinggi diharapkan dapat mengelola kegiatan penelitian yang memenuhi standar berikut : standar arah, proses, hasil, kompetensi, pendanaan, sarana dan prasarana, dan outcome (Ditlitabmas, 2013).

Fakultas Teknik Universitas Diponegoro yang merupakan Fakultas terbesar. FT UNDIP juga sebagai penyumbang hasil riset terbesar setiap tahunnya telah memilki Rencana Strategis Tahun 2015-2020, yang berisikan analisis situasi, kebijakan, sasaran, program, serta indikator capaian kinerja, dirancang dengan harapan terjadinya kesinambungan antara kebijakan, program, dan kegiatan dalam mewujudkan visi Fakultas Teknik serta visi Universitas Diponegoro. Indikator Kinerja Fakultas Teknik (IKFT) sebagai bagian penting dari Renstra Fakultas Teknik telah dirumuskan sebagai parameter untuk mengukur keberhasilan dalam satu periode kepemimpinan, yang disusun berdasarkan pada visi, misi, dan tujuan Fakultas Teknik Universitas Diponegoro. Dalam Renstra FT secara umum terdapat 99 indikator yang telah dirancang, namun belum terdapat pengelompokkan indikator-indikator khusus untuk mengukur kapasitas riset.

Indikator kinerja dan kinerja sangat berkaitan satu sama lain, dan kedua hal ini masing-masing juga digunakan sebagai pedoman dalam menyusun rencana induk penelitian $(R I P)$. Didalam mengevaluasi atau mengukur kinerja riset dibutuhkan indikator kinerja (Key Performance Indicators) yang tepat agar dapat mencapai target dalam pengembangan kapasitas riset. Fakultas Teknik Menyatakan bahwa indikator kinerja disusun dengan baik, dengan harapan dapat memberi output kinerja riset yang baik pula, sehingga dapat menaikkan rangking Universitas Diponegoro baik secara nasional maupun internasional.

Berdasarkan website Universitas Diponegoro (Undip.ac.id) dapat diketahui prestasi UNDIP yaitu menepati posisi ke-8 di indonesia pada periode tahun 2015-2016 dengan jumlah publikasi terindeks Scopus sejumlah 1294 dokumen sampai saat ini. prestasi ini tidak cukup baik, sebab hal ini mengindikasikan bahwa Universitas Diponegoro memiliki kapasitas riset yang rendah dibandingkan dengan Universitas ternama lainnya, di lain sisi hal tersebut juga mengindikasikan bahwa keberlanjutan penelitian (Sustainability of Research) masih butuh perhatian serta tindak lanjut.

Hasil wawancara pada tanggal 16 desember 2016 silam dengan Dekan Fakultas Teknik UNDIP, menyatakan bahwa kinerja riset Fakultas Teknik dari sudut jumlah publikasi mengalami peningkatan setiap tahunnya, namun Dekan Fakultas Teknik menuturkan dengan tegas bahwa kinerja riset saat ini masih perlu dibenahi dan tingkatkan lagi untuk dapat mewujudkan Visi Fakultas dan Visi Universitas pada tahun 2020. Beliau menganjurkan bahwa kinerja riset perlu diteliti, dianalisis serta diperhatikan seksama untuk perbaikan berkelanjutan pada kapasitas riset yang ada di Fakultas Teknik UNDIP. Dekan Fakultas Teknik UNDIP juga mengatakan bahwa indikator kinerja riset perlu diteliti dan dikembagin lagi dengan tujuan, agar Fakultas Teknik memiliki target yang jelas dalam merencanakan kegiatan riset yang berjalan.

Kapasitas riset memiliki hubungan dengan keberlanjutan penelitian (Sustainability of Research), dalam konteks ini, diambil untuk Kegiatan penelitian yang dipertahankan dalam jangka menengah. Keberlanjutan suatu penelitian merupakan hal yang wajib dilakukan oleh setiap stakeholder penelitian disuatu perguruan tinggi. Berdasarkan paper 
karangan V.lynn meek mengatakan bahwa Faktor-faktor yang mempengaruhi keberlanjutan penelitian yaitu antara lain keuangan, infrastruktur dan penelitian pendukung. manajemen organisasi juga akan menjadi faktor penentu keberlanjutan penelitian, karena tanpa kepemimpinan yang memadai, manajemen dan pemasaran penelitian, penelitian akan tidak sesuai dengan ekspektasi. Aspek keberlanjutan penelitian sangat berdampak besar terhadap kapasitas riset, sebab aspek ini merupakan aspek yang paling utama dan harus dipenuhi dalam penelitian. Aspek keberlanjutan penelitian sangat riskan, jika aspek ini diabaikan maka penelitian tersebut akan menjadi penelitian yang berkualitas rendah bahkan bisa jadi penelitian tersebut tidak bisa berjalan.

Secara komprenshif, didalam penelitian ini akan dilakukan pengembangan indikatorindikator kinerja riset aspek keberlanjutan penelitian (Sustainability of Research) yang dipakai untuk menilai kapasitas riset Fakultas Teknik UNDIP. Indikator-indikator ini diharapkan dapat menjadi parameter keberhasilan serta dapat mendorong dalam meningkatkan kapasitas riset baik dari segi kuantitas maupun kualitas riset.

\section{METODE PENELITIAN}

Metodologi penelitian ini digunakan sebagai acuan dalam melakukan penelitian. Metodologi penelitian penelitian ini terdiri dari penentuan model konseptual, penentuan metode, teknik pengambilan data, dan tahap usulan atau rekomendasi perbaikan.

\section{Penentuan model konseptual}

Berdasarkan ide yang diadopsi dari paper referensi karangan V. Lynn Meek dan Jeannet J. Van der Lee pada tahun 2005 berjudul "Performance Indicators For Assessing and Benchmarking Research Capacities in Universities", ditemukan 4 kriteria pengukuran kualitas riset. Empat kriteria itu antara lain yaitu Impact Of Research, Sustainability Of Researh, Importance Of Research dan Potential Of Research. Pada penelitian ini, penulis hanya mengadopsi 1 kriteria yaitu Sustainability Of Researh sebagai aspek dalam menilai kapasitas Riset Fakultas Teknik UNDIP.

Model konseptual menggambarkan tentang variabel penelitian yang digunakan untuk mendapatkan Key Performance Indicator (KPI) sebagai indikator dalam sistem penilaian kapasitas riset. Dalam Pengembangan KPI, peneliti menggunakan metode delphi untuk menyusun KPI dengan acuan dari beberapa jurnal internasional, QS World University Rangkings dan RENSTRA FT UNDIP. Semua KPI (Key Performance Indicator) yang dikembangkan berkaitan dengan Keberlanjutan penelitian yang menjadi Aspek Utama pada penelitian ini. Faktor-faktor yang mempengaruhi keberlanjutan penelitian yaitu antara lain keuangan, manajemen organisasi, penelitian pendukung dan infrastruktur.

Berikut disajikan gambar 4 yang merupakan model penelitian ini :

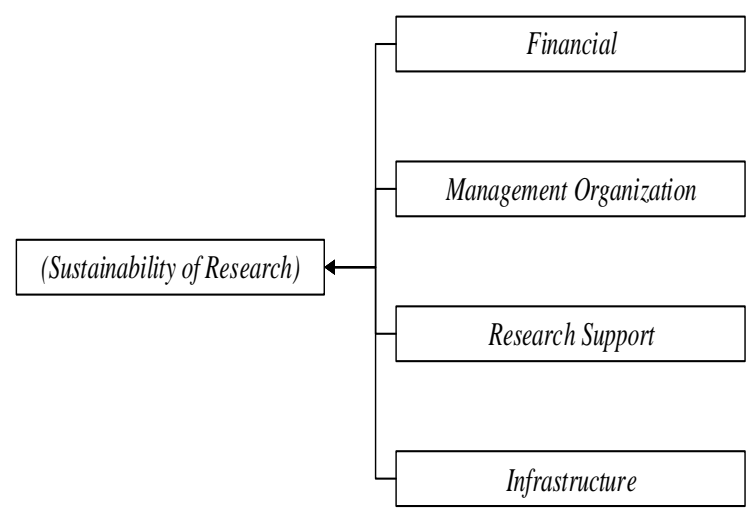

Gambar 4 Model Penelitian 


\section{Penentuan Metode}

Data akan diolah menggunakan pendekatan delphi untuk validasi Indikator yang dirancang, pendekatan AHP untuk pemberian bobot terhadap indikator dari setiap kategori keberlanjutan penelitian dan pendekatan OMAX (Objective matrix) untuk memberi score terhadap pencapaian kapasitas riset.

\section{Validasi KPI dengan Metode Delphi}

Kuisioner Pengecekkan Validasi KPI

- Tujuan : Dilakukan untuk mengetahui apakah KPI yang telah disusun sesuai dengan kebutuhan UPPM FT UNDIP untuk menilai kapasitas riset.

- Populasi : Dekan Fakultas Teknik UNDIP, Wakil Dekan I, dan Ketua UPPM FT UNDIP

- Langkah : - penilaian dan revisi KPI ( delphi Putaran 1)

- penilaian dan revisi KPI ( delphi Putaran 2)

Berikut disajikan gambar validasi KPI Gambar 5

\begin{tabular}{|c|c|c|c|}
\hline No. & Kategori Faktor & $\begin{array}{c}\text { KPI (Key Pefformance } \\
\text { Indicators) }\end{array}$ & Definisi Operasional \\
\hline 1 & Financial & $\begin{array}{l}\text { Jumlah dana penelitian dari } \\
\text { pendanaan } \\
\text { interasional joint research } \\
\text { intermasional (P1) }\end{array}$ & $\begin{array}{l}\text { Semua dana yang digunakan dalam keberlanjutan } \\
\text { penelitian yang berasal dari kerjasama instansi } \\
\text { internasional. }\end{array}$ \\
\hline & & & Tidak Setuju \\
\hline
\end{tabular}

Gambar 5 Validasi KPI (Metode Delphi)

\section{Pembobotan dengan Metode Analitycal Hierarchy Process ( AHP)}

Metode Analitycal Hierarchy Process ( AHP) digunakan untuk mengetahui bobot dari tiap-tiap KPI yang telah dirumuskan. Pembobotan ini dilakukan dengan cara :

1. Melakukan Perbandingan Berpasangan antar KPI

2. Menghitung Perataan rasio konsistensi

3. Melakukan Pembobotan Elemen-elemen KPI dengan AHP

Berikut sajikan gambar 6 contoh kuesioner perbandingan berpasangan.

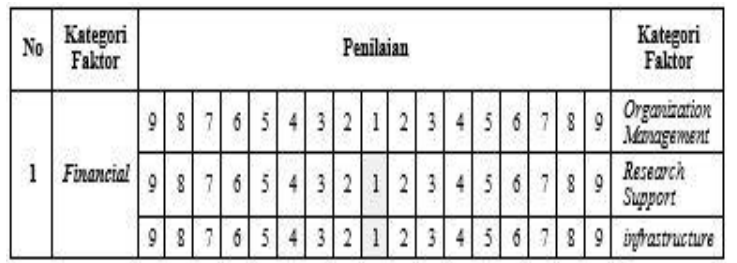

Gambar 6 Contoh Kuesioner Perbandingan Berpasangan

\section{Scoring System dengan Menggunakan OMAX}

Objective Matrix ( OMAX) digunakan untuk mengetahui sejauh mana pencapaian kinerja objek yang diteliti. Konsep dari penilaian ini adalah penggabungan beberapa kriteria kelompok kerja dalam suatu matrik. Setiap kriteria kinerja memiliki sasaran berupa jalur khusus untuk perbaikan serta memiliki bobot sesuai dengan tingkat kepentingannya terhadap tujuan organisasi. Didalam OMAX dilakukan hal-hal sebagai berikut :

1.Menentukan Target KPI

2.Melakukan Perhitungan kelas pencapaian elemen KPI

3. Menentukkan nilai terendah tiap KPI

4. Melakukan Scoring dengan OMAX 


\section{Teknik Pengambilan Data}

Tahap pengumpulan data akan memberikan gambaran mengenai langkah-langkah pengumpulan data dan jenis data yang dikumpulkan dalam penelitian. Data-data yang akan dikumpulkan dalam penelitian diperoleh dengan telah studi pustaka maupun wawancara. Teknik pengumpulan data yang digunakan dalam penelitian ini antara lain:

a. Data sekunder yang dipakai adalah data Indikator Kinerja Undip yang didapatkan dari Buku Rencana Strategis Fakultas Teknik Undip 2015-2020. Serta data kriteria penilaian QS World University Ranking digunakan oleh Undip sebagi acuan untuk penilaian QS World World University Ranking setiap tahunnya dan beberapa jurnal internasional lainnya

b. Wawancara dilakukan untuk mengetahui indikator kinerja Riset Fakultas Teknik Undip

c. Kuesioner validasi KPI yang telah dikembangin berdasarkan sumber-sumber yang valid dan dalam menentukan urutan bobot kepentingan dari KPI (Key performance indicators).

Data-data yang dibutuhkan pada penelitian sebagai berikut :

\begin{tabular}{|l|l|l|}
\hline Identifikasi & Data yang dibutuhkan & Sumber Data \\
\hline Gambaran Umum \\
Perguruan Tinggi khusus \\
$\begin{array}{l}\text { Fakultas Teknik UNDIP \& } \\
\text { UPPM FT UNDIP }\end{array}$ & $\begin{array}{l}\text { Data Fakultas Teknik } \\
\text { UNDIP secara Global } \\
\text { meliputi Visi, Misi, } \\
\text { Tujuan, Strategi Bisnis }\end{array}$ & $\begin{array}{l}\text { Kepala Bagian Tata Usaha } \\
\text { dan UPPM FT UNDIP }\end{array}$ \\
\hline $\begin{array}{l}\text { Identifikasi Key } \\
\text { performance indicators }\end{array}$ & $\begin{array}{l}\text { Tema sasaran Strategis } \\
\text { riset }\end{array}$ & $\begin{array}{l}\text { Pimpinan Fakultas Telnik } \\
\text { dibantu oleh Pimpinan } \\
\text { UPPM FT UNDIP }\end{array}$ \\
\hline $\begin{array}{l}\text { Validasi Key performance } \\
\text { inaicators yang telah } \\
\text { disusun }\end{array}$ & Kuisioner Validasi KPI & $\begin{array}{l}\text { Pimpinan FT UNDIP, } \\
\text { Wakil Dekan I, Pimpinan } \\
\text { UPPM FT UNDIP. }\end{array}$ \\
\hline $\begin{array}{l}\text { Pembobotan masing- } \\
\text { masing KPI dengan } \\
\text { Menggunakan AHP }\end{array}$ & $\begin{array}{l}\text { Kuisioner Perbandingan } \\
\text { Berpasangan yang berisi } \\
\text { indikator keberhasilan dan } \\
\text { tolak ukur riset }\end{array}$ & $\begin{array}{l}\text { Pimpinan FT UNDIP, } \\
\text { Wakil Dekan I, Pimpinan } \\
\text { UPPM FT UNDIP. }\end{array}$ \\
\hline $\begin{array}{l}\text { Scoring System dengan } \\
\text { Menggunakan OMAX }\end{array}$ & $\begin{array}{l}\text { Data mengenai } \\
\text { Pencapaian, Target untuk } \\
\text { masing-masing KPI }\end{array}$ & $\begin{array}{l}\text { Pimpinan FT UNDIP, } \\
\text { Wakil Dekan I, Pimpinan } \\
\text { UPPM FT UNDIP,. }\end{array}$ \\
\hline
\end{tabular}

Gambar 7 Sumber Data

\section{Penentuan Responden Penelitian}

Pada Penelitian menggunakan teknik pengambilan sampel Judgement Sampling/Purposive Sampling. Peneliti menggunakan teknik tersebut karena metode Delphi dan AHP diisi oleh para ahli yang memang mengetahui pada bidang tersebut. Persoalan utama dalam teknik judgement adalah menentukan kriteria, dimana kriteria harus mendukung tujuan penelitian. Biasanya teknik judgement dipilih untuk penelitian yang lebih mengutamakan kedalaman data daripada untuk tujuan representatif yang dapat digeneralisasikan. (Kriyantono, 2006).

Responden yang dipilih dalam penelitian ini adalah stakeholder Fakultas Teknik Universitas Diponegoro dan merupakan pakar dalam penelitian ini. dapat dilihat pada Tabel 1 berikut :

Tabel 1 Responden

(Sumber: hasil olah data)

No Nama

Jabatan

\begin{tabular}{lll}
\hline 1 & $\begin{array}{l}\text { Ir. M. Agung Wibowo, MM, M.Sc, } \\
\text { Ph.D }\end{array}$ & Dekan Fakultas Teknik \\
\hline 2 & Prof. Dr. Moh Djaeni, ST, M.Eng & Wakil Dekan I Fakultas Teknik \\
\hline
\end{tabular}




\section{M. Facta, ST, MT, Ph.D Ketua UPPM Fakultas Teknik}

Dalam penelitian ini ketiga pakar diatas merupakan responden tetap di keseluruhan kuesioner yang di buat, antara lain : kuesioner validasi KPI, pembobotan KPI, dan kuesioner rekomendasi. Pada kuesioner penentuan target diberikan kepada Dekan FT UNDIP, selanjutnya Dekan memerintah untuk UPPM dan tim mengisi kuesioner target.

\section{Tahap Rekomendasi Perbaikan}

Setelah dilakukan pengolahan data dan Penilaian Kapasitas Riset maka didapatkan key performance indicators ( KPI ) yang perlu diperbaiki ataupun ditingkatkan untuk mencapai target dan visi dari Fakultas Teknik UNDIP, hal tersebut akan menjadi rekomendasi pertama kepada pihak yang terkait langsung dengan penelitian ini. Dalam memberi usulan rekomendasi perbaikan dilakukan dengan brainstroming dari para pakar dan juga dilakukan usulan rekomendasi dengan menggunakan metode delphi.

Metode Delphi digunakan untuk mendapatkan pendapat para ahli terhadap rekomendasi yang perlu dilakukan terlebih dahulu. Kuesioner diberikan kepada bagian stakeholder bidang riset FT UNDIP yaitu antara: Dekan Fakultas Teknik UNDIP, Wakil Dekan Fakultas Teknik UNDIP dan Ketua UPPM Fakultas Teknik UNDIP untuk memvalidasi saran rekomendasi yang dihimpun dari RIP ITB, BPMA UI,RISTEKDIKTI dan menjaring saran rekomendasi perbaikan lainnya dari pakar diatas

\section{HASIL DAN PEMBAHASAN}

Pengolahan data dan perhitungan yang dilakukan didapatkan hasil dan analisis mengenai kapasitas riset di Fakultas Teknik dan dapat mengetahui nilai dari setiap kategori faktor keberlanjutan penelitian.

\section{Pengembangan Key Performance Indicators}

Indikator-indikator (KPI) yang dikembangkan berasal dari jurnal internasional, Permenristekdikti, Kepmenristekdikti dan QS World University Rangkings. Terdapat 20 KPI yang terdiri atas 10 KPI diambil dari Renstra FT UNDIP dan 10 KPI yang diambil dari sumber lainnya. KPI (Key Performance Indicators) yang dikembangkan yaitu antara lain terdiri atas 1 KPI kategori faktor keuangan (Financial), 3 KPI kategori faktor manajemen organisasi (organization management) , 4 KPI kategori faktor riset pendukung (Research Support) dan 2 KPI kategori faktor infrastructure (Infrastructure). Dari kategori faktor keuangan indikator yang dikembangkan yaitu Jumlah dana penelitian dari pendanaan nasional (pemerintah) sumber QS World University Rangkings, dari kategori faktor Management organization yang dikembangkan adalah indikator insentif tambahan yang diberikan pada peneliti sumber Permenristek dikti, Indikator International Staff sumber paper karangan V.Lynn Meek, Indikator Staff with PHD sumber QS World University Rangkings.

Dari kategori faktor riset pendukung indikator yang dikembangkan yaitu Article in journal, Participation in editorial Boards, Conference Reports sumber Jurnal karangan Gianfranco tahun 2001, indikator Prolific Academic Experts sumber QS World University Rangkings. Dari Kategori faktor infrastruktur indikator yang dikembangkan yaitu Jumlah pusat unggulan sumber Kepmenristek Dikti dan Indikator Library Acquisitions sumber QS World University Rangkings. Semua Indikator yang telah disusun akan terlebih dahulu dilakukan validasi oleh stakeholder Fakultas Teknik UNDIP dengan menggunakan metode delphi dengan tujuan penyesuaian indikator-indikator yang akan digunakan dengan objek yaitu riset Fakultas Teknik UNDIP. 
Hasil pengumpulan data delphi putaran pertama yaitu terdapat perbedaan pendapat antara responden mengenai KPI dari kategori faktor manajemen organisasi. Perbedaan itu terletak pada indikator international staff, adapun 2 responden tidak setuju dengan indikator tersebut. Di sisi lain terdapat penambahan indikator yang diusulkan oleh responden yaitu kategori faktor riset pendukung dengan indikator jumlah HKI. Hasil Akhir Delphi Putaran pertama adalah 19 KPI yang disetujui dan 1 KPI Usulan dari responden yang dibawa ke delphi putaran kedua. Pada Delphi Putaran kedua semua KPI disetujui di jadikan indikator dalam menilai kapasitas riset FT UNDIP.

\section{Penentuan Bobot KPI}

Berdasarkan hasil kuesioner yang dibagikan kepada stakeholder Fakultas Teknik UNDIP dan diolah menggunakan tools Analytical Hierarchy Process didapatkan bobot dari setiap KPI (key performance indicators).

Terdapat 20 sub-kategori faktor (KPI), yang terdiri atas 6 KPI pada kategori faktor keuangan, 3 KPI pada kategori faktor manajemen organisasi, 6 KPI pada kategori faktor pendukung riset dan 5 KPI pada kategori faktor infrastruktur. Sub-kategori faktor (KPI) tersebut akan dilakukan perbandingan berpasangan sehingga didapatkan bobot masingmasing dari tiap sub-kategori faktor dari setiap responden, kemudian dilakukan kombinasi nilai bobot antara seluruh responden dengan menggunakan software expert choice v.11. Berikut hasil rekapitulasi nilai bobot gabungan dari responden.

Tabel 2 Bobot KPI

(Sumber: hasil olah data)

\begin{tabular}{|c|c|c|c|c|}
\hline NO & $\begin{array}{l}\text { Kategori } \\
\text { Faktor }\end{array}$ & KPI & $\begin{array}{l}\text { Hasil } \\
\text { Pembobotan }\end{array}$ & Nilai Konsistensi \\
\hline \multirow{6}{*}{1} & \multirow{6}{*}{ Financial } & $\mathrm{P} 1$ & 0,83 & \multirow{6}{*}{0,02} \\
\hline & & $\mathrm{P} 2$ & 0,149 & \\
\hline & & P3 & 0,178 & \\
\hline & & $\mathrm{P} 4$ & 0,19 & \\
\hline & & P5 & 0,183 & \\
\hline & & P6 & 0,217 & \\
\hline \multirow{3}{*}{2} & \multirow{3}{*}{$\begin{array}{l}\text { Organization } \\
\text { Management }\end{array}$} & $\mathrm{T} 1$ & 0,444 & \multirow{3}{*}{0,03} \\
\hline & & $\mathrm{T} 2$ & 0,16 & \\
\hline & & $\mathrm{T} 3$ & 0,396 & \\
\hline \multirow{6}{*}{3} & \multirow{6}{*}{$\begin{array}{l}\text { Research } \\
\text { Support }\end{array}$} & $\mathrm{R} 1$ & 0,361 & \multirow{6}{*}{0,03} \\
\hline & & $\mathrm{R} 2$ & 0,065 & \\
\hline & & R3 & 0,094 & \\
\hline & & $\mathrm{R} 4$ & 0,124 & \\
\hline & & $\mathrm{R} 5$ & 0,092 & \\
\hline & & R6 & 0,264 & \\
\hline \multirow{5}{*}{4} & \multirow{5}{*}{ Infrastructure } & $\mathrm{F} 1$ & 0,214 & \multirow{5}{*}{0,01} \\
\hline & & $\mathrm{F} 2$ & 0,151 & \\
\hline & & F3 & 0,333 & \\
\hline & & $\mathrm{F} 4$ & 0,132 & \\
\hline & & F5 & 0,17 & \\
\hline
\end{tabular}




\section{Scoring Hasil Pencapaian Kapasitas Riset FT UNDIP}

Pengolahan data pada tahap scoring dilakukan setelah dilakukan penilaian serta pembobotan KPI. Nilai score didapatkan dengan menentukkan terlebih dahulu persentasi pencapaian berdasarkan data tahun 2016 kemudian langkah selanjutnya dilakukan perhitungan interval untuk setiap score dan setiap pada tabel OMAX. Dalam menentukkan score dari hasil pencapaian dilakukan dengan mencocokkan nilai pencapaian dengan nilai interval, jika tidak ada nilai yang sesuai maka dilakukan pendekatan dengan nilai interval terdekat dengan nilai pencapaian. Dan apabila masih sulit menentukkan maka dilakukan interpolasi pada KPI yang belum diketahui score.

Dalam penelitian ini didapatkan score yang berbeda-beda dari setiap KPI yang digunakan. Terdapat 9 KPI yang memiliki score pada rentang 8-10 (Warna Hijau), 4 KPI yang memiliki score pada rentang 4-7 (Warna Kuning), 7 KPI yang memiliki score pada rentang 0-3 (Warna Merah). Berdasarkan hasil score yang didapatkan terhadap 20 KPI dalam penelitian, terdapat 6 KPI yang memiliki score tertinggi yaitu KPI P3,P4,T1,R6,F1,dan F2. Terdapat pula 4 KPI yang memiliki score terendah yaitu KPI $\mathrm{P} 2, \mathrm{P} 5, \mathrm{~T} 2$ dan R3.

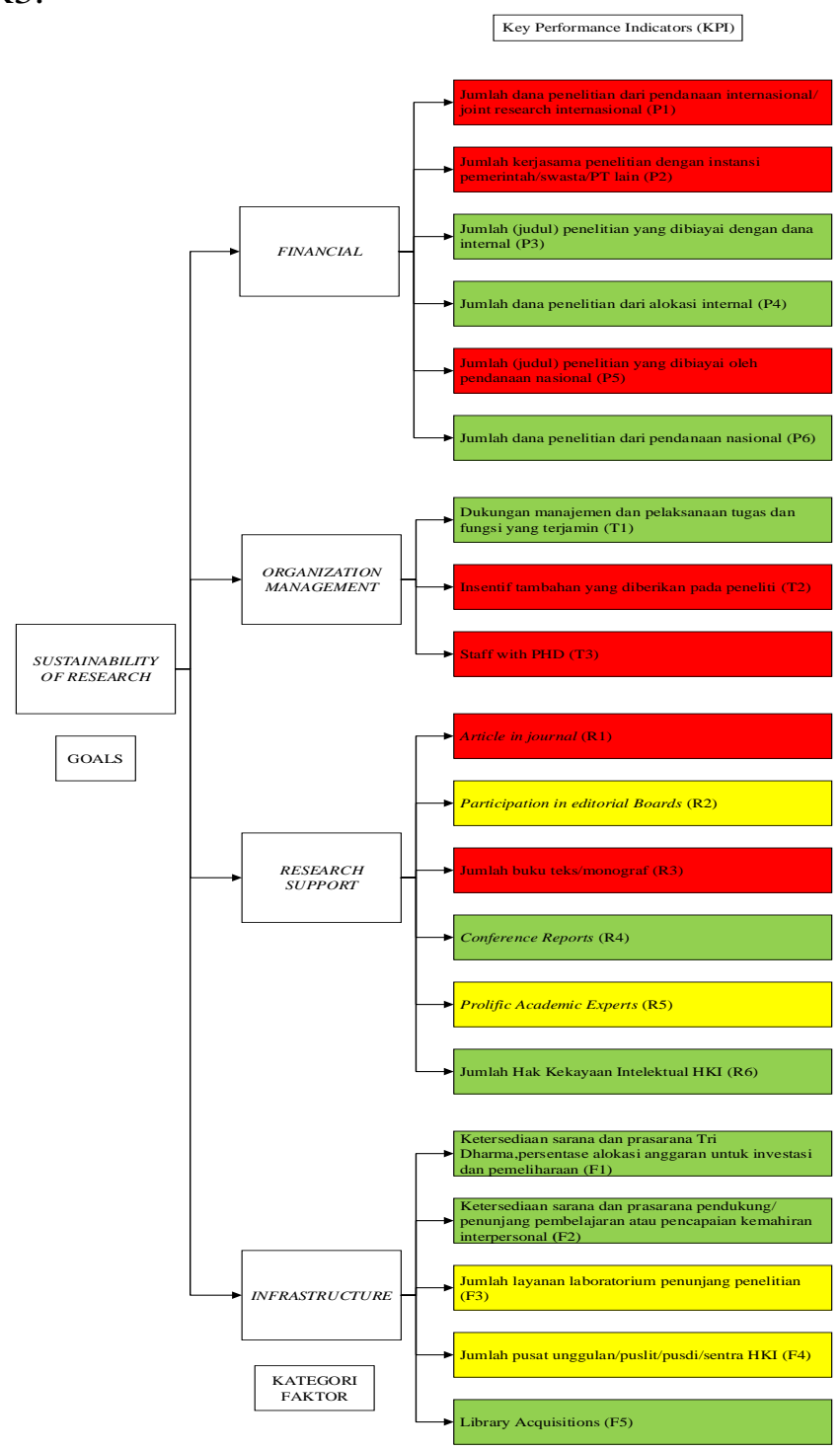

Gambar 8 Struktur Hirarki AHP Sustainability Of Reseach Setelah Dilakukan Penilaian 


\section{Indeks Pencapaian kategori Faktor Keberlanjutan penelitian}

Berdasarkan pengolahan data diatas maka didapatkan pencapaian dari setiap kategori faktor, sebagai berikut :

Tabel 3 Indeks Pencapaian Kategori Faktor (Sumber: hasil olah data)

\begin{tabular}{lll}
\hline NO & Kategori Faktor & Pencapaian \\
\hline 1 & Financial & 7,906 \\
\hline 2 & $\begin{array}{l}\text { Management } \\
\text { Organization }\end{array}$ & 5,628 \\
\hline 3 & Research Support & 4,713 \\
\hline 4 & Infrastructure & 8,171 \\
\hline
\end{tabular}

Terdapat 3 kategori faktor keberlanjutan penelitian yang masih lampu kuning, hal ini memberi informasi bahwa faktor keberlanjutan penelitian masih perlu dilakukan perbaikan berkelanjutan (Continous Improvement). Faktor infrastruktur merupakan kategori faktor yang memiliki pencapaian tertinggi dibandingkan kategori faktor lainnya. Sedangkan kategori faktor pendukung riset memilki pencapaian terendah dibandingkan kategori faktor lainnya. Pada penelitian ini tidak terdapat kategori faktor yang memilki score dibawah nilai 3 atau sama dengan 3. Hal ini membuktikan bahwa faktor keberlanjutan penelitian Fakultas Teknik Universitas Diponegoro cukup baik.

\section{Rekomendasi Perbaikan}

Berdasarkan pengolahan data yang dilakukan, terdapat beberapa indikator (KPI) yang mendapatkan perhatian utama untuk dilakukan improvisasi program, namun Sebaliknya juga terdapat KPI yang hasil pencapaiannya melebihi target dari FT UNDIP. Key performance Indicators yang memiliki score dibawah 3 merupakan KPI yang butuh perhatian utama untuk dilakukan perbaikan dengan melaksanakan program penunjang dalam meningkatkan pencapaian indikator. KPI tersebut antara lain sebagai berikut : Jumlah kerjasama penelitian dengan instansi pemerintah/swasta/PT lain (P2), Jumlah (judul) penelitian yang dibiayai oleh pendanaan nasional (P5), Insentif tambahan yang diberikan pada peneliti (T2), Article in journal (R1), dan Jumlah buku teks/monograf (R3).

Berdasarkan hasil delphi rekomendasi putaran pertama, dapat dilihat pada Gambar 8 \& 9 tidak terdapat perbedaan pendapat antara pakar sehingga diambil kesimpulan bahwa semua rekomendasi dapat diterima menjadi rekomendasi perbaikan untuk meningkatkan performansi KPI aspek keberlanjutan penelitian. 


\begin{tabular}{|c|c|c|c|}
\hline No. & $\begin{array}{l}\text { Kategori } \\
\text { Faktor }\end{array}$ & KPI & Rekomendasi Perbaikan \\
\hline \multirow{6}{*}{1} & \multirow{6}{*}{ Financial } & \multirow{2}{*}{$\begin{array}{l}\text { Jumlah dana penelitian dari } \\
\text { pendanaan } \\
\text { internasional joint } \\
\text { research internasional } \\
\text { (Renstra FT UNDIP, 2015) }\end{array}$} & $\begin{array}{l}\text { FT Undip wajib aktif menijlin hubungan Eksternal ke negara-negara yang altif } \\
\text { melakukan penelitian. (RIP ITB) }\end{array}$ \\
\hline & & & $\begin{array}{l}\text { Mengadakan pelathan khusus untuk meninglkatkan Kemampuan Bahasa Inggris dan } \\
\text { tata cara untuk menulis artikel pada jumal imiah internasional (RIP ITB) }\end{array}$ \\
\hline & & \multirow{2}{*}{$\begin{array}{l}\text { Jumlah kerjasama } \\
\text { penelitian dengan instansi } \\
\text { pemerintahswastaPT lain } \\
\text { (Renstra FT UNDIP,2015) }\end{array}$} & $\begin{array}{l}\text { Aktif Menjalin Kerjasama instansi pemerintah, perusahaan BUMN, Perusahaan Swasta } \\
\text { untuk membantu menyelesaikan permasalahan yang terjadi di tingkat nasional maupun } \\
\text { tingkat perusahaan }\end{array}$ \\
\hline & & & $\begin{array}{l}\text { sinergi pemberdayaan masyarakat di wilayah binaan UNDIP sebagai wujud } \\
\text { implementasi hasil dan kerjasama dalam kegaiatan penelitian di masyarakat. }\end{array}$ \\
\hline & & \multirow{2}{*}{$\begin{array}{l}\text { Jumlah (judul) penelititin } \\
\text { yang dibiayai oleh } \\
\text { pendanaan nasional } \\
\text { (Renstra FT UNDIP,2015) }\end{array}$} & $\begin{array}{l}\text { Memiliki program yang bersifat antar-disiplin yang mensinergikan berbagai bidang } \\
\text { sains, teknologi dan seni. }\end{array}$ \\
\hline & & & $\begin{array}{c}\text { Menciptakan penelitian yang outputanya berdampakk secara nasional serta memecahkzan } \\
\text { permasalahan yang ada di masyarakat. }\end{array}$ \\
\hline \multirow{3}{*}{2} & \multirow{3}{*}{$\begin{array}{l}\text { Organization } \\
\text { Management }\end{array}$} & $\begin{array}{l}\text { Insentif tambahan yang } \\
\text { diberikan pada peneliti } \\
\text { (Permenristekdikti,2015) } \\
\end{array}$ & $\begin{array}{l}\text { Menerapkan kebijakan memberi insentif tambahan kepada peneliti atas prestasi nya } \\
\text { dalam kegiatan riset unggulan }\end{array}$ \\
\hline & & & peningkatan keterlibatan Dosen S3 dalam kegiatan riset dan publikasi \\
\hline & & $\begin{array}{l}\text { Staff with PHD (QS World } \\
\text { University Rangkings) }\end{array}$ & $\begin{array}{l}\text { meningkatkan jumlah dosen S3 dengan memberi bantuan tunjangan melanjutkan di } \\
\text { perguruan tinggi luar negeri }\end{array}$ \\
\hline
\end{tabular}

Gambar 9 Rekomendasi perbaikan pada kategori Financial dan Organization Management

\begin{tabular}{|c|c|c|c|}
\hline No. & $\begin{array}{l}\text { Kategori } \\
\text { Faltor }\end{array}$ & KPI & Rekomendasi Perbaikan \\
\hline \multirow{8}{*}{3} & \multirow{8}{*}{$\begin{array}{l}\text { Research } \\
\text { Support }\end{array}$} & \multirow{2}{*}{ Article in journal } & $\begin{array}{l}\text { memfasilitasi terbentuknya kerja sama riset dan publikasi antara dosen doltor muda } \\
\text { (Peneliti Penguusul) dengan dosenn peneliti lain yang mempunyai rekam jejak sangat } \\
\text { baik (Peneliti Pengarah), }\end{array}$ \\
\hline & & & $\begin{array}{l}\text { mengadopsi dan mencontoh budaya penelitian yang baik dari kelompok peneliti yang } \\
\text { lebih maju di perguruan tingugi lain dalam melaaksanakan penelitian yang bermutu } \\
\text { melakukuan publikasi interasional bereputasi }\end{array}$ \\
\hline & & \multirow{2}{*}{$\begin{array}{c}\text { Participation in editorial } \\
\text { Boards (Gianfranco dkk, } \\
\text { 2001) }\end{array}$} & $\begin{array}{l}\text { memberikan wadah bagi dosen dokktor muda untuk melaksanakan penelitian dan } \\
\text { publikasi, }\end{array}$ \\
\hline & & & $\begin{array}{l}\text { Pengembangan sistem reward \& punishment yang berorientasi pada peningkatan } \\
\text { kualitas dan produltifitas riset }\end{array}$ \\
\hline & & \multirow{2}{*}{$\begin{array}{l}\text { Jumlah buku } \\
\text { teks monograf (Renstra } \\
\text { FT UNDIP, 2015) }\end{array}$} & Memotivasi dan mengarahkan peneliti untuk pembuatan buku dan monograf \\
\hline & & & nembantu peneliti \\
\hline & & \multirow[t]{2}{*}{$\begin{array}{l}\text { Prolific Academic } \\
\text { Experts (QS World } \\
\text { University Rangkings) }\end{array}$} & $\begin{array}{l}\text { Menghasilkan IPTEKS baru atau memberikan dampak manfiaat langsung yang seluas- } \\
\text { luasnya terhadap perkembangan, perubahan dan kesejahteraan masyarakat serta } \\
\text { sekaligus memberikan benefit kepada UNDIP. Dalam hal pengembangan teknologi, } \\
\text { kegiatan riset institusi berorientasi outcome di masyarakat dan menghasilkan } \\
\text { multiproduk. }\end{array}$ \\
\hline & & & Berorientass pada kebutuhan IPTEKS dan masyarakat. \\
\hline \multirow{4}{*}{4} & \multirow{4}{*}{ Infrastructure } & \multirow{2}{*}{$\begin{array}{c}\text { Jumlah layanan } \\
\text { laboratorium penunjang } \\
\text { penelitian (Renstra FT } \\
\text { UNDIP, 2015) }\end{array}$} & $\begin{array}{l}\text { Peningkatan Pengadaan Peralatan Laboratorium yang Signifikan untuk membantu } \\
\text { peneliti }\end{array}$ \\
\hline & & & $\begin{array}{l}\text { Meningkatkan layanan laboratorium untul memfasilitasi peneliti dalam } \\
\text { menyelesaikan penelitian }\end{array}$ \\
\hline & & \multirow{2}{*}{\begin{tabular}{|c|} 
Jumlah pusat unggulan \\
(Kepmenristekdikti,2015)
\end{tabular}} & Revitalisasi Pusat-pusat Penelitian dan Pusat pusat unggulan. \\
\hline & & & Membangun Pusat Unggulan yang berkolaborasi Rumpun Ilmu yang ada di UNDIP \\
\hline
\end{tabular}

Gambar 10 Rekomendasi perbaikan pada kategori Research Support dan Infrastruce

\section{KESIMPULAN DAN SARAN}

Berdasarkan penelitian yang telah dilakukan, maka dapat diambil beberapa kesimpulan sebagai berikut :

Pengembangan KPI (Key Performance Indicators) pada area riset Fakultas Teknik Universitas Diponegoro digunakan untuk mendorong dalam meningkatkan kuantitas dan kualitas riset. KPI dikembangkan dari Qs World University Rangkings, Permenristekdikti, Jurnal internasional karangan gianfranco (2011), dan Kepmenristekdikti. KPI yang dikembangkan telah divalidasi oleh stakeholder Fakultas Teknik Universitas Diponegoro dengan menggunakan metode delphi sehingga telah sesuai dengan visi-misi Fakultas Teknik Universitas Diponegoro. Terdapat 9 KPI yang dikembangkan antara lain sebagai berikut : Jumlah dana penelitian dari pendanaan nasional (pemerintah), Insentif tambahan yang diberikan pada peneliti, Staff with PHD, Article in journal, Participation in editorial Boards, Conference Reports, Prolific Academic Experts, Jumlah pusat unggulan riset dan Library Acquisitions.

Pada penelitian hanya mengadopsi 1 kriteria yaitu Sustainability Of Researh sebagai aspek dalam menilai kapasitas Riset Fakultas Teknik UNDIP. Aspek keberlanjutan penelitian dipengaruhi oleh beberapa kategori faktor yaitu keuangan (financial), manajemen organisasi (Organization Management), Pendukung riset (Research Support) dan Infrastruktur(infrastructure). Berdasarkan hasil penilaian yang dilakukan maka 
didapatkan indeks pencapaian dari setiap kategori faktor antara lain sebagai berikut : Indeks Pencapaian Financial (Keuangan) sebesar 1,423, Organization Management sebesar 1,632, Research Support sebesar 1,159 dan infrastructure sebesar 2,328. Dari data nilai indeks diatas dapat diketahui bahwa indeks yang paling tinggi terdapat pada kategori faktor infrastructure dan yang paling rendah pada kategori faktor research support. Hal ini mengindikasikan bahwa kapasitas riset Fakultas Teknik Universitas Diponegoro dari kategori faktor research support, diperlukan perhatian khusus untuk dilakukan perbaikan sehingga dapat meningkatkan performansi dari indikator-indikator dari research support.

Dari pengolahan data yang dilakukan, terdapat beberapa indikator (KPI) yang mendapatkan perhatian utama untuk dilakukan improvisasi program, namun Sebaliknya juga terdapat KPI yang hasil pencapaiannya melebihi target dari FT UNDIP. KPI yang memiliki score dibawah 3 merupakan KPI yang butuh perhatian utama untuk dilakukan perbaikan. KPI tersebut antara lain sebagai berikut : Jumlah kerjasama penelitian dengan instansi pemerintah/swasta/PT lain (P2), Jumlah (judul) penelitian yang dibiayai oleh pendanaan nasional (P5), Insentif tambahan yang diberikan pada peneliti (T2), Article in journal (R1), dan Jumlah buku teks/monograf (R3). Pada tahap rekomendasi dilakukan pengumpulan program-program dari literatur yang sesuai dengan KPI. Rekomendasi perbaikan dilakukan dengan metode delphi dalam me-validasi, alhasil semua rekomendasi yang ditawarkan disetujui oleh ketiga pakar dalam penelitian ini. Hasil rekomendasi terdapat pada tabel 5.2 Contoh Rekomendasi perbaikan yang tertera pada tabel 5.2 antara lain sebagai berikut : Mengadakan pelatihan khusus untuk meningkatkan Kemampuan Bahasa Inggris dan tata cara untuk menulis artikel pada jurnal ilmiah internasional (RIP ITB), meningkatkan jumlah dosen S3 dengan memberi bantuan tunjangan melanjutkan di perguruan tinggi luar negeri, Pengembangan sistem reward \& punishment yang berorientasi pada peningkatan kualitas dan produktifitas riset dan Revitalisasi Pusat-pusat Penelitian dan Pusat pusat.

\section{REFERENSI}

Abdoellah. (2012). Rencana Induk Penelitian Universitas Padjadjaran. Bandung : LPPM UNPAD

Carotenuto, G.d. (2001). Evaluating Research Performance: the Strategyof the university of naples federico II (Italy). Higher Education Policy, 75-90

Ditlitabmas. (2013). Panduan Penilaian Kinerja Penelitian Perguruan Tinggi. Jakarta: Dikti.

DRPM Ditjen. (2017). Panduan Penelitian Peningkatan Kapasitas di Perguruan Tinggi. Jakarta: Ristekdikti.

Hanna,dkk. (2012). Pedoman Penjaminan Mutu Internal Program Riset Universitas Indonesia. Depok: BPMA UI

Huselid, M., Beatty, R., \& An Schneier, C. E. (2003). New HR Metric. Scoring on The Business Scorecard, Organizational Dynamics.

Ir. M. Agung Wibowo, M. P. (2016, Desember 16). Pengukuran Kinerja Riset FT UNDIP. (M. Z. S, Interviewer)

ITB. (2016). Rencana Induk Penelitian Tahun 2016-2020. Bandung: LPPM ITB.

Lee, V. M. (2015). Performance Indicators for Assessing and Benchmarking Research Capacities in Universities. Australia: APEID, UNESCO Bangkok.

Latifah. (2005). Prinsip-Prinsip Dasar Analytical Hierarchy Process. Medan: Universitas Sumatra Utara (USU)

Mona. (2016,January 13). Laporan kinerja UPPM FT UNDIP. Diambil Kembali dari uppm.ft.undip.ac.id: http://uppm.ft.undip.ac.id/laporan-kinerja/ 
PENGEMBANGAN INDIKATOR KINERJA UTAMA

Ary Arvianto. Et al.

UNTUK MENGUKUR KEBERLANJUTAN PENELITIAN

PADA FAKULTAS TEKNIK UNIVERSITAS DIPONEGORO

Powell,C. (2003). The Delphi technique. United State : Us National Library of Medicine Institutes Health

Prawirosentono, S. (1999). Kebijakan Kinerja Karyawan. Yogyakarta: BPFE.

Riggs, J. (1987). Production Systems: Planning, Analysis, and Control. John Wiley \& Sons,.

Rudd, E. (2006). The evaluation of the quality of Research. Studies in Higher Education, $37-41$.

Saaty, T. L. (2008 ). Decision making with the analytic hierarchy process. Int. J. Services Sciences, 83-98.

Salmi, J. (2009). The Challenge of Establishing world-class Universities. Washington: WorldBank 